\title{
TRENDS OF BOARD DIVERSITY: WHO SITS IN A BOARDROOM?
}

\author{
Syaiful Baharee Jaafar ${ }^{1 *}$ and Mohd Mohid Rahmat ${ }^{2}$ \\ ${ }^{1}$ Department of Commerce, \\ Polytechnic of Tuanku Sultanah Bahiyah, Kedah, Malaysia \\ ${ }^{2}$ Center for Governance Resilience and Accountability, \\ National University of Malaysia, Malaysia
}

\begin{abstract}
The diversity of a board provides good information for decision-making. In addition, having individuals from different backgrounds and having unique knowledge sets, experiences and skills lead to better governance. The objective of this study was to investigate trends of diversity in the boardroom in publicly listed Malaysian companies. The study was conducted on a sample of 337 companies listed on Bursa Malaysia with 674 observations from $2015 \& 2016$. The findings show that the diversity of boards with respect to gender, age, education, and ethnicity is beneficial. Most corporations prefer to appoint men to the board of directors. The results of the study show that when it comes to age and ethnicity, diversity becomes a priority for companies to compete in the open market. In addition, the findings indicate that knowledge, which is related to education and qualifications, is a very important element for sitting in the boardroom. In addition, education, diversity has a positive significance in a family firm. Family members need to be better qualified to ensure that the company is able to survive in the market for longer periods.
\end{abstract}

Keywords: board diversity, family firm, education diversity, age diversity

\section{ARTICLE INFO}

\section{Article History:}

Received: 8 April 2020

Accepted: 16 April 2021

Published: 31 August 2021

* Corresponding Author: Syaiful Baharee Jaafar. E-mail: syaiful_1974@yahoo.com.my 


\section{INTRODUCTION}

Performance is achieved through best strategies and planning, and this relates to shareholder satisfaction with their investment. Providing information is very important for designing better strategies that lead to efficient business transactions. The focus of activities is dependent upon the design of the strategy. Therefore, the beginning stage in strategy design is collecting input, and the boardroom is a place where information is provided through brainstorming (Al-Gamrh et al., 2018; Al-Matari et al., 2012; Ciftci et al., 2019; Amin et al., 2019).

What is the relationship between the board of directors and the boardroom? A board of directors is a group of people who are responsible for all the business decision-making to be aligned to achieving better performance (Al-Matari et al., 2012; Amin et al., 2019; Ararat et al., 2015; Ciftci et al., 2019), which is associated with shareholder satisfaction. Additionally, a board brainstorms to generate ideas in the meeting room, also known as the boardroom. A boardroom is a place where relevant comments from board discussions are connected to the operation of a company. Furthermore, it shows that the diversity of the board is very important regarding the information provided (Hillman et al., 2000; Rutledge et al., 2016). While diversity is voluntary for companies, there are no specific regulations set out in the Code of Best Practices for Corporate Governance for Diversity. Consequently, we questioned the diversity of the board of directors.

In this study, diversity includes gender, education, ethnicity, and age. Companies should have a mixed-gender on the board because different backgrounds and experiences based on one's gender are beneficial to a company's growth (Ararat et al., 2015; Ciftci et al., 2019; Shukeri et al., 2012). Hillman et al. (2000) stated that a different kind of board may provide different beneficial resources to a company. Education refers to knowledge on a board of directors and having different levels of education can improve performance. Cheng et al. (2010) found that a degree level qualification held by the chairman was positively related to performance. Furthermore, different cultures, values, and beliefs may be an advantage for companies to keep their business successful in the long term (Alazzani et al., 2017; Abdullah, 2014; Abdul Wahab et al., 2015). Without diversity on the board of directors, decisions can be influenced by gender bias and racism. 
Members of the board of directors have different backgrounds, values, gender experiences, and education (Alazzani et al., 2017; Boadi \& Osarfo, 2019; Harjoto et al., 2019), but they have similar goals and objectives with regard to a firm's overall objective. Supported by Hillman et al. (2002, p. 749), the human capital on demographically diverse boards should result in divergent and unique views and backgrounds brought to a firm. They also found that the demographics of directors can influence the strategic choices of the company due to differences in human and social capital between directors of different races and genders (Hillman et al., 2002). This study was interested in exploring the unique characteristics of board members, which can benefit a firm's operation.

Carter et al. (2003) and Erhardt et al. (2003) investigated board diversity and found that both racial and gender diversity in the boardroom positively influenced firm performance (Tee \& Rassiah, 2020; MorenoGomez et al., 2018). As a result, the firm is able to expand its business operations through investments (Bernile et al., 2018; Midavaine et al., 2016). Therefore, Eulerich et al. (2014) stated that most particular national and international policymakers consider board diversity is associated with better performance. However, although various organizations want to have a diverse board structure still the implication of board diversity to firm performance is uncertain (Hassan \& Marimuthu, 2018; Kang et al., 2007; Uribe-Bohorquez et al., 2018), particularly in developing countries including Malaysia (Amin et al., 2019).

Diversity on boards is an advantage for companies to capture various market segmentation and improve their performance. Differences in gender, age, education, and ethnicity are closely associated with values, beliefs, and culture. The diversity of boards provides a firm with better strategies and planning to achieve its objectives. As a result of this notion, shareholder satisfaction can increase because of their increased wealth.

The purpose of this paper was to examine diversity trends in a boardroom of listed companies in Malaysia. The paper also examined the association between the attributes of board diversity (age, ethnicity, gender, and educational diversity) and family-owned companies. This study argued that controlling founders and their family members may dominate board positions, including the board members' nomination and appointment (Gul 
\& Zhang, 2016; Salloum et al., 2019). Family-owned businesses have strong incentives to continue to control and maintain operations over an extended period. However, there is limited evidence to show which attributes of diversity are more important among family-owned companies in Malaysia. Thus, this study would provide an essential landscape for family firms' board diversity.

Based on the sample size of 337 firms listed on Bursa Malaysia with 674 observations from 2015 and 2016, this study found patterns of diversity regarding gender, age, education, and ethnicity. The majority of companies prefer to appoint males on their board of directors. With respect to age and ethnicity, the findings show that diversity has become a priority among companies to be competitive in the open market. Furthermore, the results indicated that knowledge, which is linked to education and qualifications, is a very important element in becoming a board member. The findings further indicate that family firm has a significant relationship to the diversity of education.

This study is very important to provide insights into Malaysian firm practices in terms of board diversity. This study also recommends when to appoint a member of the board of directors in the boardroom. Thus, each board member is a key individual in the business that leads the business to future success. The diversity of boards, such as gender, age, education, and ethnicity, are all important aspects for members to take into account when managing commercial activities. Also, it helps to identify the types of board diversity that the family firm typically practices. A family-owned company prefers to appoint a family member to support the company's success and stay longer.

The remaining chapters are organized as follows: Section 2 outlines the relevant literature while fully developing the ideas of past research that are most important to the present study. The research design issues and methodology are explored in Section 3. Details of the final sample and the measurement of variables are also discussed in this section. The results and discussion are presented in Section 4. Section 5 sets out the conclusions, limitations, and some suggestions for further research. 


\section{LITERATURE REVIEW}

Blue (1977, p. 276) defined diversity as "the great number of different statuses among which a population is distributed." Because "race and gender are often considered proxies of different perspectives individuals bring to organizations" (Tee \& Rassiah, 2020; Fernández-Temprano \& Tejerina-Gaite, 2020; Hillman et al., 2002, p. 749; Moreno-Gomez et al., 2018), the human capital on demographically diverse boards should result in divergent and unique views and backgrounds brought to a firm. The boardroom becomes homogenous if the board of directors is made up of male-only without female directors or Chinese only without other ethnicities (Tee \& Russia, 2020; Guest, 2019). Requirements for diversity in a board of directors are not mandatory for companies to comply with. However, a company tends to gain benefits from board diversity, such as knowledge, skills, development of the company, relationship and others (Kang et al., 2007; Terjesen et al., 2015; Uribe-Bohorquez et al., 2018).

Diversity is very important to the board of directors in decision-making because it provides a wider range of information (Hillman et al, 2000). Besides, diversity also can enhance company performance as previous studies have stated (Al-Matari et al., 2012; Amin et al., 2019; Ararat et al., 2015; Ciftci et al., 2019). For example, Li et al. (2011) argued that diversity of directors can increase skills and knowledge, which leads to improved firm performance. These findings were consistent with Zahra and Pearce (1989), who explained that diversity among the board of directors may generate new and different ideas, which links with better performance. However, the decision to apply board diversity in the boardroom is not based on moral grounds only but decisions are made based on cost-benefit concerns (Sarhan et al., 2018).

This section will discuss diversity related to gender, age, education, and ethnicity matters. Furthermore, it will show that the pattern of diversity in the boardroom may apply in the corporate world.

\section{Director's Gender}

The issue of gender diversity on corporate boards purported contributions of women directors, including improved monitoring, ethical 
focus, and democratic leadership (Unite et al., 2019). This rationale forms the perception of the importance of women's participation on corporate boards to oppose alternative arguments based on social or equality considerations (Moreno-Gomez et al., 2018; Unite et al., 2019) since board structure is normally dominated by males. The gender difference is considered as diversity and is an important element in a board of directors. Therefore, gender issues have become subject to research by many scholars (Branson, 2012; Terjesen et al., 2009; Moreno-Gomez et al., 2018; Unite et al., 2019) and can create policies in many countries to improve the representation of women on boards (Branson, 2012). Many countries have their quotas for women representatives on boards such as Norway, France, and Spain ( $40 \%$ of board members are women), Belgium (35\%), and Malaysia (30\%) (Deloitte, 2011). This statistic shows that the composition between females and males in boards is a national issue.

Malaysia is similar to other developing countries which face gender issues. For example, in Indonesia, s study revealed that the average percentage of women on the boards of 383 listed firms on the Indonesia Stock Exchange (IDX) was 11.2 percent (Darmadi, 2011). Thus, the board of directors being dominated by men became a norm for most of the companies in developing countries. Many studies on gender diversity in the Malaysian context have been conducted (Abdullah \& Ku Ismail, 2013; Shukeri et al., 2012; Marimuthu \& Kolandaisamy, 2009). A study by Marimuthu and Kolandaisamy (2009) used data from 2000 to 2006 for the top 100 non-financial firms and found that women directors occupied $13.5 \%$ of the positions. Furthermore, results from Shukeri et al. (2012) indicated that only $9.8 \%$ of women sat on boards throughout the data from 300 randomly selected firms for 2011. Abdullah and Ku Ismail (2013) used data from 100 non-financial firms listed on Bursa Malaysia's website since 2007. This study reported that women directors represented $6.3 \%$ of board members. A previous discussion showed the Malaysian government's ability to influence company policies, according to gender.

Mixed-gender is beneficial for a company to understand the market according to their different backgrounds, skills, and experiences. The market is very competitive according to the different beliefs, cultures, backgrounds, education experiences, gender, and age (Fernández-Temprano $\&$ Tejerina-Gaite, 2020). Therefore, the presence of mixed gender is very 
important to keep businesses aligned with market needs. For example, who can understand women behavior better than women directors? Brennan and McCafferty (1997) explained that women directors can understand women consumers' behavior and needs. Another benefit of women directors is creativity and innovation, which leads to capturing more of the market and better decision making. This shows that the presence of women on boards possibly increases firm performance and shareholder wealth (Ripley, 2003). Kang et al. (2007), explained that when women were on a board, the corporation's value possibly increased. The recent evidence by Moreno-Gomez et al. (2018) also supports gender diversity in which women's leadership is associated with subsequent business performance. Additionally, Pandey et al. (2020) found that female presence on the board of Australian firms was negatively associated with the cost of debt which supports the argument that a certain threshold of gender balance is required for enhancing board effectiveness.

The board meeting is a place for board members to address opinions, ideas, and solutions for company problems, plus their progress in the future. All boards have the right to give suggestions related to the problem, but the decision made may still be biased to the gender of the member - especially if the board is dominated by one gender. Therefore, a mixed-gender board might play a role as a check and balance system, which benefits a firm (Moreno-Gomez et al., 2018; Unite et al., 2019).

In Asian countries, including Malaysia, the male is a family leader who is responsible to fulfill the basic needs of his family. Furthermore, they are required to protect and provide a better life for their family. Therefore, males have better motivation to work harder and are highly committed, which is good for companies to gain better performance. However, female directors also play important roles in improving firm performance. According to Neilsen and House (2010, p. 138), a woman director has "a concern with the welfare of other people and being affectionate, helpful, kind, sympathetic, interpersonally sensitive, nurturing and gentle." From this, gender issues in a company need to be looked at further. 


\section{Director's Age}

Another question is whether young or old persons should sit on the board of directors? Why is age relevant in the boardroom? What happens if a young director dominates the board? What age can be considered old? The elements of knowledge, experience, and skills are related to a range of ages. A board with a range of ages can generate more ideas that benefits a company (Fernández-Temprano \& Tejerina-Gaite, 2020). The combination of young directors' technological competency with older directors' experience can build a strong relationship with interested parties which benefits a company.

Differences between young and old, which can be referred to as the generation gap, is where each age range has its own traditions, beliefs, and values. A young director is very energetic, able to work long hours, and tends to lead better performance. When young directors joined a company, they are more likely to know early-career entrepreneurs (Ali et al., 2014). The reverse is true for old directors who are very experienced and may become a part of the check and balance system with young directors. In addition, they have friends outside the company, which is beneficial to a business relationship.

However, there are mixed results according to age and performance. For example, one study by Siciliano (1996) showed that a high board age diversity had a positive relationship with large donations for a non-profit organization. This finding was supported by Mahadeo et al. (2012) and Kagzi and Guha (2018) who found that high board age diversity was related to high profits for organizations. A contrasting result was found by Hafsi and Turgut (2013) who found that board age diversity is related to low corporate social performance. Other findings indicated that board age diversity does not have a significant relationship with return on assets (ROA) and return on equity (ROE) (Jhunjhunwala \& Misra, 2012; Bonn et al., 2004; Jonson et al., 2020)

\section{Director's Education Background}

Education refers to the knowledge that someone gains either formal or non-formal. Formal education refers to the education system from primary to higher education. Non-formal education refers to gaining knowledge through 
life and experience. According to formal education, knowledge refers to a qualification such as a diploma, degree, master, and a Ph.D., meaning that when people gain a higher level of qualification, this indicates that the person is knowledgeable. According to Gottesman and Morey (2006), educational qualification reflects intelligence. Thus, the firm should have a board with higher education and perhaps even become a requirement for being appointed to the board.

Members in the boardroom should consist of knowledgeable people. The implication of this notion is that it makes the board generate better ideas and strategies to capture market needs. If they lack knowledge, it could possibly affect and influence firm performance. This shows that boards consist of people who have a responsibility to make sure firm objectives are achieved. This is a consistent finding with Jalbert et al. (2002), Bhagat et al. (2010), and Cheng et al. (2010). All three studies found evidence that education level is positively associated with financial performance. Although a recent study by Kagzi and Guha (2018) involving Indian knowledgeintensive firms found that education diversity negatively influences firm performance, the empirical evidence suggesting that educational diversity improves firm performance is more prominent (Bhagat et al., 2010; Boadi \& Osarfo, 2019; Cheng et al., 2010; Harjoto et al., 2019).

According to the Agency Theory, shareholders transfer authority to the board of directors to ensure that a firm's objectives are achieved. Therefore, the board of directors' responsibility is to keep a successful business in the long term. They play a role to increase firm wealth through better performance. When shareholders trust the board of directors, who are able to increase their wealth, then the investment may either remain or increase. Trust here is related to better education qualifications because the person is seen as more knowledgeable. Meaning, shareholders prefer a board of directors consisting of people who have the knowledge and know how to run the business operations successfully (Bhagat et al., 2010; Boadi \& Osarfo, 2019; Cheng et al., 2010; Harjoto et al., 2019; Kagzi \& Guha, 2018).

\section{Director's Ethnicity}

Why is ethnicity an issue within a board of directors? Is it very important for firm survival? Customers' values, cultures, and beliefs need 
to be congruent with those of the board of directors, which links them to a firm's objective (Azmat \& Rentschler, 2015). In addition, it is very tough to capture the market if the board's ethnicity is homogenous. They only understand their environment which is not necessarily consistent with other ethnicities' needs. This scenario may cause failure to capture the market concerning a lack of understanding of the customer's background.

Additionally, ethnicity may contribute to different religions, which may lead to different market segments. Therefore, failure to understand ethnicity may affect the product segmentation with regard to a religious base. Sensitivity on ethnic issues needs to be emphasized by a firm to ensure that the product or service will be accepted because with regard to one's ethnic values and beliefs, there could be a product that one might not be able to use (Tee \& Rassiah, 2020). The success of a product or service on the market may ensure the interest of shareholders. Therefore, it is very important to understand customer's values and beliefs because they are linked to the product that is competing in the marketplace. When this scenario does not happen, the shareholder may feel dissatisfied because of the way it affects its wealth.

There are two possibilities shareholders may take action on, such as withdrawal of their shares or put pressure on the firm to work harder to enhance firm performance (Guest, 2019). Therefore, the roles played by board members as coming from different ethnic backgrounds should be used to address ideas and strategies. The implication of this notion is that it may be able to fulfill market demand and enhance firm performance (Azmat \& Rentschler, 2015; Guest, 2019; Tee \& Rassiah, 2020). According to Carter et al. (2003), field evidence showed that there is a positive relationship between the percentage of ethnic minorities on a board and a firm's performance. However, Gul and Zhang (2016) posited a possibility of a concave function relationship between ethnic diversity and firm performance.

\section{Board Diversity and Family Firm}

A family firm prefers to appoint a family member as part of the board of directors by using their power as a founder and controlling majority shareholder (Villalonga \& Amit, 2006; Rahmat et al., 2018). Who is sitting in the boardroom in the family firm? Without further discussion, the family 
firm prefers to hire a family member without any preferred gender. Anyone, regardless of gender, can be appointed as the board of directors as long as he/she is a family member. This situation may change the pattern of board diversity in a family firm.

The family firm puts less priority on appointing the board of directors outside of family members. This shows that age is not an issue as either young or older members can join the board of directors as long as they are family members. A young director is very knowledgeable in relation to the present situation, especially in technological aspect and beneficial for a family firm. However, if all family members involved in the boardroom are young directors, it may not be good for a business because old directors have experience and a good relationship with other firms (Jonson et al., 2020). This shows that age diversity in the family firm may differ from a non-family firm. Additionally, Bjuggren et al. (2018) emphasized that there are many more males than female corporate leaders. However, their results indicate that female leadership has a much more positive impact on the performance of family firms than that of non-family firms. Vieira (2018) also found that family firm performance is a premium or higher when they have more gender diversity than their counterparts.

It is very important for a family firm to have better strategies and planning to capture market segmentation because it may influence firm performance. Without better knowledge, experience, and skills, this may not be realized. Therefore, family firms prefer to have a board of directors with a better educational background to prolong the business. Family members have to further their studies in higher education, such as at degree, master, or doctoral level to gain better knowledge and skills. According to Li et al. (2011) who argued that the diversity of directors should increase the skills and knowledge of the board, which leads to improved firm performance.

Thus, educational diversity among board members provides a different level of knowledge which is beneficial for family firms especially in the complexity of business nowadays (Bhagat et al., 2010; Boadi \& Osarfo, 2019; Cheng et al., 2010; Harjoto et al., 2019). Each board member, including family members, has better ideas to enhance better performance. However, family members may be appointed to sit on the board of directors by cronies when procedures or policies are not strictly followed (Gul \& 
Zhang, 2016; Rahmat et al., 2018; Sarkar \& Selarka, 2020). The minimum requirement to be on a board of directors is holding a degree, but this requirement may be ignored for family members.

Additionally, Malaysia is a multiracial country that has many ethnicities such as Malays, Chinese, Indians, and others (Gul \& Zhang, 2016; Tee \& Rassiah, 2020). Each ethnic group has its own beliefs, values, and culture that influence business strategies and planning. Therefore, a homogenous board does not apply in the Malaysian culture, but it is different in family firms. The family firm prefers to appoint the board of directors from a similar ethnic group to avoid conflicts between board members regards to beliefs, values, and culture (Salloum et al., 2019). The family firm may be able to focus on its business activities to achieve better outcomes.

However, studies about board diversity attributes among family firms are scarce, which leads this study to hypothesize that certain characteristics of board diversity (age, ethnicity, education, and gender) may be associated with family firms.

H1: There is a positive relationship between board diversity and family firms

\section{RESEARCH METHODOLOGY}

This study was based on a sample of 337 firms listed on Bursa Malaysia with 674 observations from 2015 and 2016. Data was extracted from Bursa Malaysia (www.bursamalaysia.com) manually collected from the annual reports. Bursa Malaysia was once known as the Kuala Lumpur Stock Exchange (KLSE). In 2004, it was renamed Bursa Malaysia. It consisted of the Main Market (Main Board and Second Board) and ACE Market (effective starting 3 August 2009) and is an exchange-holding company approved under Section 15 of the Capital Markets and Services Act 2007.

Data was analyzed using the SPSS and results indicated the mean, standard deviation, correlation, and regression. Regression analysis used variables tested by proxies by dependent variables such as family firm, and independent variables such as diversity are gender, age, ethnicity, and 
education. Regression analysis was used to test the association between the pattern of board diversity (age diversity, gender diversity, ethnic diversity, and education diversity) and the family firm. This regression provided empirical evidence about board diversity patterns that is commonly practised in family firms.

Equation (1) describes the model used to test the relationship between the family firm, age diversity, gender diversity, ethnic diversity, and education diversity.

Family-Firm $=\beta 0+\beta 1$ Gender-Diversityit $+\beta 2$ Age-Diversityit + $\beta 3$ Ethnicity-Diversityit $+\beta 4$ Education-Diversityit + eit .

Table 1: Measurement of Variation

\begin{tabular}{|c|c|c|}
\hline No & Variables & Measurement \\
\hline 1 & Family_Firm & $\begin{array}{l}\text { FAM_FIRMS takes the value of } 1 \text { for family firms and } \\
\text { zero otherwise }\end{array}$ \\
\hline 2 & Gender_Diversity & $\begin{array}{l}\text { Gender was divided into two categories, male and } \\
\text { female. Gender diversity took a value of } 1 \text { for the } \\
\text { presence of a female on the board of directors. Gender } \\
\text { Non-diversity took a value of zero when all board of } \\
\text { directors were male. }\end{array}$ \\
\hline 3 & Age_Diversity & $\begin{array}{l}\text { Age category was divided into old as over } 60 \text { years and } \\
\text { young below } 60 \text { years. Age Diversity took a value of } \\
1 \text { for the presence of a young board which was below } \\
60 \text { years. Age Non-Diversity took a value of zero when } \\
\text { all board of directors was over } 60 \text { years. }\end{array}$ \\
\hline 4 & Ethnicity_Diversity & $\begin{array}{l}\text { Ethnicity category was divided into Malays, Chinese, } \\
\text { Indians, and Foreigners. Ethnicity diversity took the } \\
\text { value of } 1 \text { for the presence of Malays, Chinese, Indian, } \\
\text { and foreigners. Ethnicity Non_Diversity took a value of } \\
\text { zero when all board of director were similar in ethnicity. }\end{array}$ \\
\hline 5 & Education_Diversity & $\begin{array}{l}\text { Education was divided into two categories as degree } \\
\text { and above and diploma and below. Education Diversity } \\
\text { took a value of } 1 \text { for the presence of the board with a } \\
\text { diploma and Education Non-Diversity took a value of } \\
\text { zero when all board members had a degree and above. }\end{array}$ \\
\hline
\end{tabular}




\section{RESULTS AND DISCUSSION}

\section{Descriptive Analysis}

Table 2 shows the descriptive statistics regarding board diversity. The average board size in this study was 7.19. In addition, gender diversity indicated contrasting results between males $($ mean $=6.60)$ and females (mean $=0.59)$ sitting on the board of directors. It shows that firms prefer to appoint males rather than females as boardroom members. This is because the male director has leadership qualities and a strong charisma to lead the company and achieve better performance. Furthermore, the composition of the ages between young and old showed a mean of 3.24 and 3.96. This indicated that composition for both ages played a role to generate better ideas to capture different segmentations that lead to a successful future.

According to the education diversity results shown, the means for a diploma and below was 0.62 , and degree and above was 6.57 . The results show that the majority of the board members is that they hold a degree in higher education and beyond. It is very important for firms to have knowledgeable board members in order to survive the complexities of the market. Furthermore, ethnicity diversity means for the Malays was 2.19, Chinese was 4.59, and Indians and Foreigners was 0.10 and 0.31 . The Chinese dominated the board of directors because they are founders of the firm, which is known as a family firm. Meanwhile, the presence of Malays on the board of directors was due to government policies, experience, and political connections. Indian and foreign directors were appointed according to their expertise and knowledge.

Table 2: Descriptive Statistic

\begin{tabular}{lcccc}
\hline & Mean & Std Deviation & Minimum & Maximum \\
\hline Board Size & 7.19 & 1.826 & 4 & 13 \\
Gender Diversity & & & & \\
Director (Male) & 6.60 & 1.778 & 1 & 12 \\
Director (Female) & 0.59 & 0.841 & 0 & 5 \\
Age Diversity & & & & 9 \\
Age above 60 years & 3.24 & 1.881 & 0 & 9 \\
Age below 60 years & 3.96 & 1.839 & 0 & 4 \\
Education Diversity & & & &
\end{tabular}




\begin{tabular}{lllll} 
Degree and above & 6.57 & 2.259 & 3 & 13 \\
Ethnicity Diversity & & & & 11 \\
Director (Malays) & 2.19 & 0.379 & 0 & 12 \\
Director (Chinese) & 4.59 & 0.831 & 0 & 4 \\
Director (India) & 0.10 & 0.998 & 0 & 9 \\
Director (Foreign) & 0.31 & 1.929 & 0 & \\
\hline
\end{tabular}

\section{Crosstab Analysis}

Table 3 indicates a cross tab analysis between age, ethnicity, education, and gender on the board of directors. Findings indicated that 361 (53.6\%) companies did not have age diversity but did appoint different genders. 44 $(6.5 \%)$ companies consisted of directors from a similar level of age and gender. Interestingly, findings showed that 259 (38.4\%) companies appoint their directors from different levels of age and gender. However, 10 (1.5\%) companies preferred to have a different level of age but no gender diversity. According to ethnicity and gender, findings showed that the majority of companies, 319 (47.3\%) preferred to appoint different genders on the board rather than different ethnicities. 86 (12.8\%) of companies preferred to have one ethnicity and gender to lead their companies. Further, 221 $(32.8 \%)$ companies had ethnic and gender diversity in their boardroom. Only $48(7.1 \%)$ companies had ethnicity diversity, but no gender diversity. In addition, there were $282(41.8 \%)$ companies that did not have an education and gender diversity in their board of directors. $86(12.8 \%)$ of the companies preferred to appoint education and gender diversity to their board of directors. Further, 123 (18.2\%) companies had gender diversity, but did not have education diversity. Besides that, 183 (27.2\%) companies had education diversity, but did not have gender diversity. Initial results show that companies are aware of the importance of diversity in the global market.

Table 3: Age, Ethnicity, Education, and Gender

\begin{tabular}{llcc} 
& & \multicolumn{2}{c}{ Gender } \\
& & Diversity & Non-Diversity \\
\hline \multirow{2}{*}{ Age } & Non-Diversity & $361(53.6 \%)$ & $44(6.5 \%)$ \\
& Diversity & $259(38.4 \%)$ & $10(1.5 \%)$ \\
\hline \multirow{2}{*}{ Ethnicity } & Non-Diversity & $319(47.3 \%)$ & $86(12.8 \%)$ \\
& Diversity & $221(32.8 \%)$ & $48(7.1 \%)$ \\
\hline \multirow{2}{*}{ Education } & Non-Diversity & $123(18.2 \%)$ & $282(41.8 \%)$ \\
& Diversity & $86(12.8 \%)$ & $183(27.2 \%)$ \\
\hline
\end{tabular}


Table 4 shows a cross tab analysis between ethnicity, education, and age on the board of directors. Findings showed that 108 (16.0\%) companies preferred their board of directors to be from different backgrounds of ethnicity and age. 26 (3.9\%) companies had different ethnicities and backgrounds of education. In addition, 28 (4.2\%) companies had different levels of age but no ethnic diversity. Also, the majority of companies preferred to hire the board of directors from different ethnic backgrounds, but not in age diversity. Regarding education and age diversity among the board members, Table 4.3 shows that 191 (28.3\%) companies had different educational backgrounds and ages in their board of directors. Only $36(5.3 \%)$ companies did not have education and age diversity in their boards. The majority of companies had different educational backgrounds but not different in age. Initial findings stated that companies focus more on one gender, but prefer different backgrounds of ethnicity and levels of education among the board of directors. Male directors were dominant and were associated with Asian traditional values where the male is viewed as a leader. Ensuring better performance by leading the market segmentation is very important in terms of having ethnicity and education, diversity because of effective strategies and planning.

Table 4: Ethnicity, Education and Age

\begin{tabular}{llcc}
\hline & & \multicolumn{2}{c}{ Age } \\
& & Diversity & Non-Diversity \\
\hline \multirow{2}{*}{ Ethnicity } & Non-Diversity & $28(4.2 \%)$ & $26(3.9 \%)$ \\
& Diversity & $108(16.0 \%)$ & $512(75.9 \%)$ \\
\hline \multirow{2}{*}{ Education } & Non-Diversity & $18(2.7 \%)$ & $36(5.3 \%)$ \\
& Diversity & $191(28.3 \%)$ & $429(63.7 \%)$ \\
\hline
\end{tabular}

Table 5 indicates the cross tab analysis on education and ethnicity, diversity in the board of directors. Results showed that 165 (24.5\%) companies had different education levels and backgrounds of ethnicity. However, 90 (13.4\%) companies did not have education and ethnicity diversity in their boards. The majority of companies preferred to hire a board of directors with better qualifications (i.e. Higher education degrees and above) and different ethnic backgrounds. Initial results indicated that companies preferred board members from different ethnic backgrounds but better education levels. It shows that firms emphasised knowledge, together 
with culture and values among directors, which helps to ensure they can capture market segmentation that leads to better performance.

Table 5: Education and Ethnicity

\begin{tabular}{clcc} 
& & \multicolumn{2}{c}{ Education } \\
& & Diversity & Non_Diversity \\
\hline Ethnicity & Non-Diversity & $44(6.5 \%)$ & $90(13.4 \%)$ \\
\hline & Diversity & $165(24.5 \%)$ & $375(55.6 \%)$ \\
\hline
\end{tabular}

Table 6 shows the pattern of board diversity in public listed companies. Results show that the majority of companies prefer to appoint men as directors. The higher number of companies have males sitting on the board of directors with 6 persons (71), followed by 7 persons (68) and 5 persons (62). Further, 22 companies had 10 or more male board members. Besides, 82 companies had either 8 or 9 males as board members. Initial results showed that Malaysia and Asian countries with a traditional culture in which the male is viewed as a leader and is responsible to make decisions and as such appoint more men to be on the board of directors. However, 202 companies were not interested in hiring a female on the board of directors to operate the business. Further, 92 companies appointed at least one female to sit on the board. Only one company preferred to have 4 and 5 female directors. Initial results indicate that culture and values may affect a female director's appointment. Further, they are deficient in leadership skills related to decision-making and may be more influenced by emotions that can affect the business operations.

Age diversity refers to persons less than 60 years of age and more than 60 years of age. Table 6 shows a similar result where 9 persons aged less than 60 years sat on the boards, and those over 60 years were 4 companies. As the results show, 66 companies had board members who are under 60 years with at least 3 persons. Further, 67 companies had at least 3 persons over 60 years sitting in their boardroom. Findings show that 5.3\% (18) companies were less interested in hiring board members who were under 60 years and $3.3 \%$ (11) of companies did not prefer to hire directors who were over 60 years. Initial results show that companies may prefer to have a balanced age diversity to ensure the segmentation between generations is filled. 
Findings showed differences in educational diversity. Companies did not prefer to hire board members who had diploma or below. The majority of companies, $69.1 \%$ (233) were not interested in hiring those who had a diploma or below. However, some of the companies may hire a few directors who have less educational qualifications. Only $0.6 \%$ (4) of the companies had 4 persons who sat on their board of directors. Otherwise, at least 3 persons on the board had better qualifications, such as a degree and above. Interestingly, findings showed that 28 companies who had more than 10 persons sitting on their board had degrees and above. Initial results showed that knowledge is very important to ensure the strategies and planning are aligned with market segmentation.

Ethnicity diversity showed the difference between Malays, Chinese, Indians and Foreigners who sat on the boards. Findings showed that $92 \%$ (310) and $84.9 \%$ (286) of the companies were not interested in hiring Indians and foreigners in the board of directors. Only 5.6\% (19) of companies preferred to appoint Chinese to sit in the boardroom. In addition, 20.2\% (56) of the companies did not have Malays on their board of directors. The majority of the board of directors consisted of Malays and Chinese. Initial results showed that the majority of companies were controlled by the Chinese, which provides space for the ethnic group to dominate the board.

\section{Correlation Analysis}

Table 7 indicates the correlation matrix between board diversity. There is a significant positive correlation between male directors with other diversity components. Further, the result showed that there is a negative relationship between male director and female director $(t=-0.1178, p<$ 0.01 ). When males become a majority in the board of directors the vice versa is female possibility becomes a minority. There is also a significant negative correlation between young and old directors $(t=-0.518, p<0.01)$.

Regarding ethnicity diversity, findings showed a significant negative correlation between Malay directors compared to Chinese directors $(t=$ $-0.613, p<0.01)$ and Indian directors $(t=-0.071, p<0.01)$. The results show that when the Malays dominated the board of directors the other ethnicities (e.g. Chinese, Indian and Foreign) may be less and vice versa. There is a significant negative correlation between degree and above, and diploma and below $(p=-0.366, p<0.010 .000)$. 


\section{Regression Analysis}

Table 8 indicates the relationship between a family firm and board diversity. Regression results indicated a positive and significant relationship between a family firm and education, diversity $(0.008 ; t=2.643$ and $p<$ 0.05 ). This study found evidence that educational diversity is significantly positive for a family firm. This analysis suggested that firms need better ideas for planning and strategies through their board of director's knowledge base. Further, family members require the knowledge to ensure that the firm can capture market segmentation and enhance performance. This evidence is consistent with several past studies that suggested the importance of educational diversity on the board such as Bhagat et al. (2010), Boadi \& Osarfo (2019), Cheng et al. (2010), Harjoto et al. (2019), and Kagzi \& Guha (2018). Therefore, family members need to further their studies at a higher level of learning to gain knowledge, skills, and experience before being able to join a family business.

That said, non-family members who are appointed to a board position also need to have the right qualification. Nowadays, business is complicated because of technological changes which influence business operations. Without better knowledge and skills, the possibility for the firm to dominate market segmentation is less and this impacts firm performance. The firm may hand it over to a family member and ensure the business is sustainable so knowledge, skills, and experience should be considered as important factors.

However, there was no significant relationship between gender diversity, age diversity and ethnic diversity, and a family firm. These findings suggest that family firms may not emphasize age, gender, and ethnic diversity on the board. It can thus be interpreted regarding the relationship between gender diversity and a family firm, that a family firm prefers to appoint a board member among the family members, either male or female. As a result, diversity is less applied in a family firm. The non-presence of age diversity may indicate that a family firm prefers experienced family members to have power and control the business. So age diversity is not a priority, except for family members. The family firm is also interested in appointing board members of similar ethnicity due to of similar values, beliefs, and culture. 
Asia-Pacific Management Accounting Journal, Volume 16 Issue 2

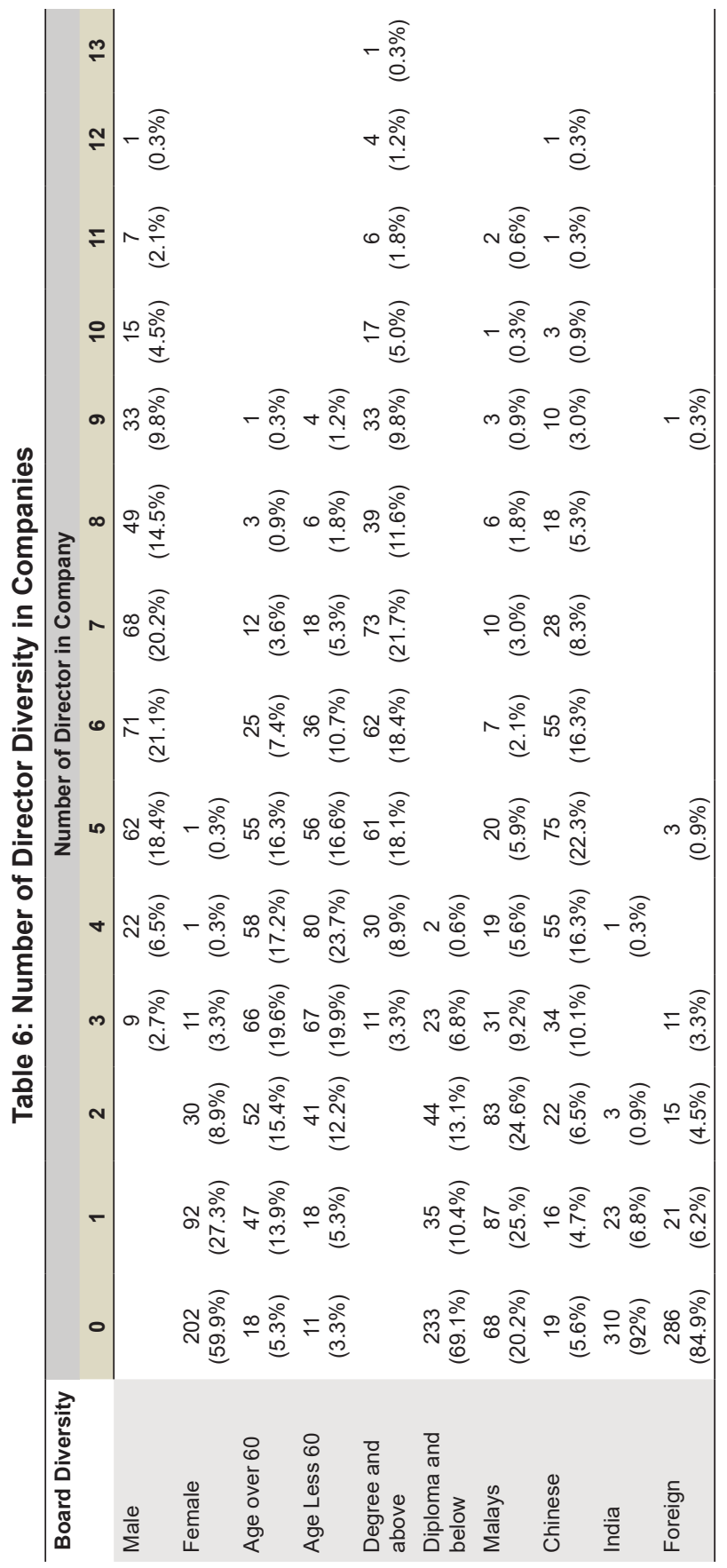




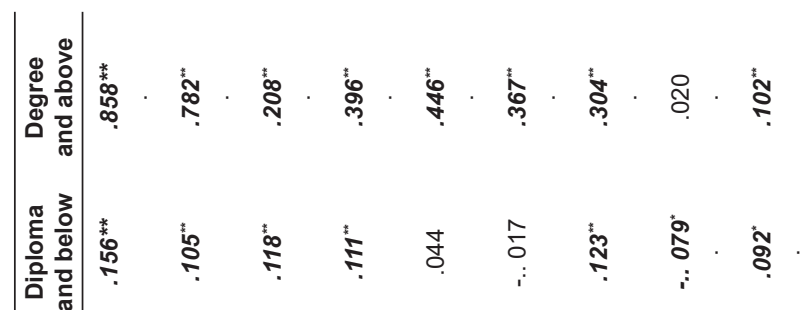

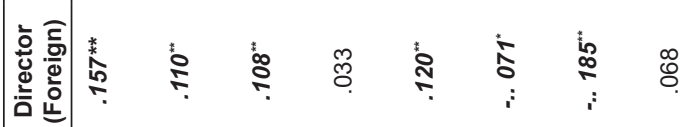

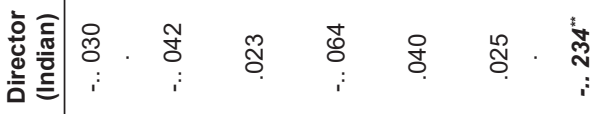

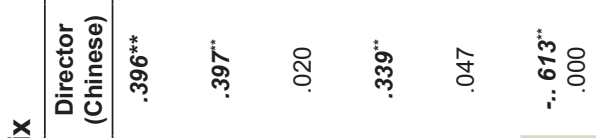

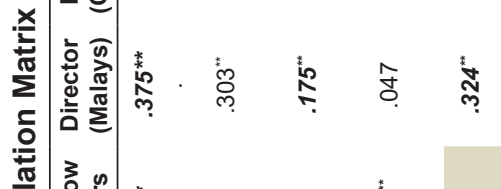

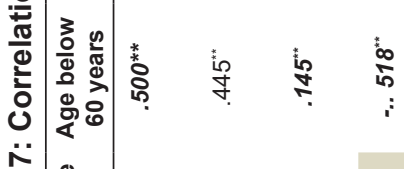

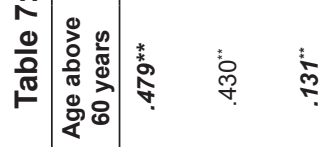

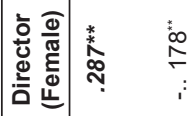

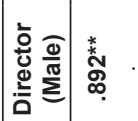

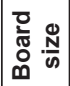

: 
Table 8: Determination of Family Firm by Board Diversity

\begin{tabular}{cc}
\hline & FAM_FIRMS \\
\hline GENDER DIVERSITY & 0.256 \\
AGE DIVERSITY & 1.137 \\
ETHNICITY DIVERSITY & 0.677 \\
EDUCATION DIVERSITY & -0.417 \\
& 0.800 \\
CONSTANT & -0.254 \\
& 0.008 \\
Adjusted R & $2.643^{* *}$ \\
F-statistic & 0.000 \\
& $6.984^{* *}$ \\
Cross-sections & 0.007 \\
Total Observation & $2.154^{\star *}$ \\
\hline
\end{tabular}

Notes: Gender diversity takes a value of 1 for male and zero for female, Age diversity takes a value of 1 old over 60 years and zero for young below 60 years, Ethnicity diversity takes the value of 1 for Malays, the value of 2 for Chinese, value of 3 for India and value of 4 for foreign, Education diversity takes a value of 1 for degree and above and zero for diploma and below, FAM_FIRMS takes the value of 1 for family firms and zero otherwise.

\section{CONCLUSION}

Shareholders and the board of directors should have similar objectives to mitigate agency problems. This is because the board of directors is required to work hard to achieve better performance, which is reflected in shareholder's wealth. A company that is able to pay better dividends towards shareholders is linked to better performance. This shows that the role that a board of directors plays in terms of planning, strategies, and capturing the market is very important. Board diversity is very important to understand the complexities of the market to enhance performance. Board diversity in this study was related to gender, age, education, and ethnicity. Gender diversity referred to a male and female director. The composition of the board whether young or old director showed that age diversity applies. Furthermore, qualification of a director such as a diploma and a degree and above shows education diversity. Finally, ethnic diversity consisted of Malays, Chinese, Indians and foreign directors. 
Furthermore, the findings indicated a mixed results in relation to gender diversity of board members. The majority of companies appointed more male directors rather than female directors. The Asian culture believes that the male is a family leader and has similar responsibilities as in a company scenario. Along with that, the male is also seen as being able to work long hours and outstation the family is being handled by their wives. However, a female is appointed because of different points of view according to their background and experience, which is beneficial for a company. Understanding the customers' needs both genders' opinions and experiences to be able to make effective planning and strategies. Along with this, the customers also have different ages, which is very important to capture the market. Therefore, companies prefer to have age diversity, young and old, as members of their board of directors.

Competition in the open market requires companies to hire a knowledgeable director. Therefore, most companies prefer to have a director with better qualifications such as a degree and above. Without better knowledge, it's very tough for a company to win the market. Findings also showed that ethnic diversity, as applied in this study, was due to government policies were Bumiputeras have to sit on the board of directors. This influences the majority of companies owned by the Chinese where Malays are becoming board members. Furthermore, where companies are not applying ethnicity diversity most of their board of directors are Chinese. Foreigners and Indians are lesser as members of the board of directors because they are a minority.

The limitation of this study is that the data is only from 2015 and 2016, which generalizes the results to that period. Further research should look at the relationship between board diversity in a family firm, which is unique when board members are family members. 


\section{REFERENCES}

Abdul Wahab, E. A., Pitchay, A. A., \& Ali, R. (2015). Culture, corporate governance and analysts forecast in Malaysia. Asian Review of Accounting, 23(3), 232-255.

Abdullah, S. N., \& Ku Ismail, K. N. I. (2013). Gender, ethnic and age diversity of the boards of large Malaysian firms and performance. Jurnal Pengurusan, 38, 27-40.

Abdullah, S. N. (2014). The causes of gender diversity in Malaysian large firms. Journal of Management \& Governance, 18(4), 1137-1159.

Alazzani, A., Hassanein, A. \& Aljanadi, Y. (2017). Impact of gender diversity on social and environmental performance: Evidence from Malaysia. Corporate Governance: The International Journal of Business in Society, 17(2), 266-283.

Al-Gamrh, B., Ku Ismail, K. N. I., \& Al-Dhamari, R. (2018). The role of corporate governance strength in crisis and non-crisis times. Applied Economics, 50(58), 6263-6284.

Ali, M., Ng, Y. L., \& Kulik, C. T. (2014). Board age and gender diversity: A test of competing linear and curvilinear predictions. Journal of Business Ethics, 125(3), 497-512.

Al-Matari, Y. A., Al-Swidi, A. K., Fadzil, F. H. B. F. H., \& Al-Matari, E. M. (2012). Board of directors, audit committee characteristics and the performance of Saudi Arabia listed companies. International Review of Management and Marketing, 2(4), 241-251.

Amin, S. I. M., Rahmat, M. M., \& Mohd Asri, A. K. (2019). Board diversity, industry specificity, and firm performance. Journal of Nusantara Studies, 4(2), 45-69.

Ararat, M. Aksu, M., \& Tansel Cetin, A. (2015). How board diversity affects firm performance in emerging markets: Evidence on channels in controlled firms. Corporate Governance: An International Review, 23(2), 83-103. 
Azmat, F., \& Rentschler, R. (2017). Gender and ethnic diversity on boards and corporate responsibility: The case of the arts sector. Journal of Business Ethics, 141(2), 317-336.

Bernile, G., Bhagwat, V., \& Yonker, S. (2018). Board diversity, firm risk, and corporate policies. Journal of Financial Economics, 127(3), 588-612.

Bhagat, S., Bolton, B. J., \& Subramanian, A. (2010). CEO education, CEO turnover, and firm performance. Available at SSRN 1670219.

Bjuggren, P. O., Nordström, L., \& Palmberg, J. (2018). Are female leaders more efficient in family firms than in non-family firms?. Corporate Governance: The International Journal of Business in Society, 18(2), 185-205.

Blue, P. (1977). Inequality and heterogeneity. New York: Academic Press.

Boadi, I., \& Osarfo, D. (2019). Diversity and return: The impact of diversity of board members' education on performance. Corporate Governance: The International Journal of Business in Society, 19(4), 824-842.

Bonn, I., Yoshikawa, T., \& Phan, P. H. (2004). Effects of board structure on firm performance: A comparison between Japan and Australia. Asian Business \& Management, 3(1), 105-125.

Branson, D. M. (2012). Initiatives to place women on corporate boards of directors: A global snapshot. The Journal of Corporation Law, 37(4). 793-814.

Brennan, N., \& McCafferty, J. (1997). Corporate governance practices in Irish companies. Irish Journal of Management, 17, 116-135.

Carter, D. A., Simkins, B. J., \& Simpson, W. G. (2003). Corporate governance, board diversity, and firm value. Financial Review, 38, $33-53$.

Cheng, L. T., Chan, R. Y., \& Leung, T. Y. (2010). Management demography and corporate performance: Evidence from China. International Business Review, 19(3), 261-275. 
Ciftci, I., Tatoglu, E., Wood, G., Demirbag, M., \& Zaim, S. (2019). Corporate governance and firm performance in emerging markets: Evidence from Turkey. International Business Review, 28(1), 90-103.

Darmadi, S. (2011). Board diversity and firm performance: The Indonesian evidence. Corporate Ownership \& Control, 8(2-4), 450-466.

Deloitte. (2011). Women in the boardroom: A global perspective. November.

Erhardt, N. L., Werbel, J. D., \& Shrader, C. B. (2003). Board of director diversity and firm financial performance. Corporate Governance: An International Review, 11(2), 102-111.

Eulerich, M., Velte, P., \& van Uum, C. (2014). The impact of management board diversity on corporate performance. An empirical analysis for the German two-tier system. An Empirical Analysis of the German Two-Tier System (November 8, 2013). Problems and Perspectives in Management (PPM), 12, 25-39.

Fernández-Temprano, M. A., \& Tejerina-Gaite, F. (2020). Types of director, board diversity and firm performance. Corporate Governance: The International Journal of Business in Society, 20(2), 324-342.

Gottesman, A. A., \& Morey, M. R. (2006). Does a better education make for better managers? An empirical examination of CEO educational quality and firm performance. Pace University Finance Research Paper, (2004/03).

Guest, P. M. (2019). Do board, ethnic diversity impact board monitoring outcomes?. British Journal of Management, 30(1), 53-74.

Gul, F. A., \& Zhang, L. (2016). Ethnicity, politics and firm performance: Evidence from Malaysia. Pacific-Basin Finance Journal, 40, 115-129.

Hafsi, T., \& Turgut, G. (2013). Boardroom diversity and its effect on social performance: Conceptualization and empirical evidence. Journal of Business Ethics, 112, 463-479. 
Harjoto, M. A., Laksmana, I., \& wen Yang, Y. (2019). Board nationality and educational background diversity and corporate social performance. Corporate Governance: The International Journal of Business in Society, 19(2), 217-239.

Hassan, R., \& Marimuthu, M. (2018). Contextualizing comprehensive board diversity and firm financial performance: Integrating market, management, and shareholder's perspective. Journal of Management Organization, 24(5), 634-678.

Hillman, A. J., Cannella, A. A., Jr., \& Paetzold, R. L. (2000). The resource dependence role of corporate directors: Strategic adaptation of board composition in response to environmental change. Journal of Management Studies, 37, 235-255.

Jalbert, T., Rao, R. P., \& Jalbert, M. (2002). Does school matter? An empirical analysis of CEO education, compensation, and firm performance. International Business and Economics Research Journal, 1(1), 83-98.

Jhunjhunwala, S., \& Mishra, R. K. (2012). Board diversity and corporate performance: The Indian evidence. IUP Journal of Corporate Governance, 11(3), 71-79.

Jonson, E. P., McGuire, L., Rasel, S., \& Cooper, B. (2020). Older boards are better boards, so beware of diversity targets. Journal of Management and Organization, 26(1), 15-28.

Kagzi, M., \& Guha, M. (2018). Does board demographic diversity influence firm performance? Evidence from Indian-knowledge intensive firms. Benchmarking: An International Journal, 25(3), 1028-1058.

Kang, H., Cheng, M., \& Gray, S. J. (2007). Corporate governance and board composition: Diversity and independence of Australian board. Corporate Governance: An International Review, 15(2), 194-207.

Li, J., Chu, C. W. L., Lam, K. C. K., \& Liao, S. (2011). Age diversity and firm performance in an emerging economy: Implications for crosscultural human resource management. Human Resource Management, $50,247-270$. 
Mahadeo, J., Soobaroyen, T., \& Hanuman, V. (2012). Board composition and financial performance: Uncovering the effects of diversity in an emerging economy. Journal of Business Ethics, 105, 375-388.

Marimuthu, M. \& Kolandaisamy, I. 2009. Ethnic and gender diversity in board of directors and their relevance to financial performance of Malaysian companies. Journal of Sustainable Development, 2(3), 139-148.

Midavaine, J., Dolfsma, W., \& Aalbers, R. (2016). Board diversity and R\&D investment. Management Decision, 54(3), 558-569.

Moreno-Gómez, J., Lafuente, E., \& Vaillant, Y. (2018). Gender diversity on the board, women's leadership and business performance. Gender in Management: An International Journal, 33(2), 104-122.

Neilsen, S., \& Huse, M. (2010). The contribution of women on boards of directors: Going beyond the surface. Corporate Governance: An International Journal, 18, 136-148.

Pandey, R., Biswas, P. K., Ali, M. J., \& Mansi, M. (2020). Female directors on the board and cost of debt: Evidence from Australia. Accounting \& Finance, 60(4), 4031-4060.

Rahmat, M. M., Amin, H. A. M., \& Saleh, N. M. (2018). Controlling shareholders' proxy and multiple directorships: Insight evidence from related party transactions. Asian Journal of Accounting and Governance, 9, 27-40.

Ripley, A. (2003) Equal Time. Time Europe, 162(11). Retrieved from www. time.com/time/europe/magazine

Rutledge, R. W., Karim, K. E., \& Lu, S. (2016). The effects of board independence and CEO duality on firm performance: Evidence from the NASDAQ-100 index with controls for endogeneity. Journal of Applied Business \& Economics, 18(2), 49-71.

Salloum, C., Jabbour, G., \& Mercier-Suissa, C. (2019). Democracy across gender diversity and ethnicity of Middle Eastern SMEs: How does 
performance differ?. Journal of Small Business Management, 57(1), 255-267.

Sarhan, A.A., Ntim, C. G., \& Al.Najjar, B. (2018). Board diversity, corporate governance, corporate performance, and executive pay. International Journal of Finance \& Economics, 24(2), 761-786.

Sarkar, J., \& Selarka, E. (2020). Women on board and performance of family firms: Evidence from India. Emerging Markets Review, 100770.

Shukeri, S. W., Shin, O. W., \& Shari, M. S. (2012). Does the board of characteristics affect firm performance? Evidence from Malaysian public listed firms. International Business Research, 5(9), 120-127.

Siciliano, J. J (1996). The relationship of board member diversity to organizational performance. Journal of Business Ethnics, 15, 13131320.

Tee, C. M., \& Rassiah, P. (2020). Ethnic board diversity, earnings quality and institutional investors: Evidence from Malaysian corporate boards. Accounting \& Finance, 60(4), 4257-4290.

Terjesen, S., Sealy, R., \& Singh, V. (2009). Women directors on corporate boards: A review and research agenda. Corporate Governance: An International Review, 17(3), 320-337.

Unite, A. A., Sullivan, M. J., \& Shi, A. A. (2019). Board diversity and performance of Philippine firms: Do women matter? International Advances in Economic Research, 25(1), 65-78.

Uribe-Bohorquez, M. V., Martínez-Ferrero, J., \& García-Sánchez, I. M. (2018). Board independence and firm performance: The moderating effect of institutional context. Journal of Business Research, 88, 28-43.

Vieira, E. S. (2018). Board of directors characteristics and performance in family firms and under the crisis. Corporate Governance: The International Journal of Business in Society, 18(1), 119-142. 
Villalonga, B., \& Amit, R. (2006). How does family ownership, control and management affect firm value?. Journal of Financial Economics, $80(2), 385-417$.

Zahra, S., \& Pearce, J. (1989). Boards of directors and corporate financial performance: A review and integration model. Journal of Management, 15(2), 291-334. 